\title{
Sensitivity Distributions of California Populations of Colletotrichum cereale to the DMI Fungicides Propiconazole, Myclobutanil, Tebuconazole, and Triadimefon
}

\author{
Francis P. Wong and Sharon L. Midland, Department of Plant Pathology, University of California, Riverside \\ 92521
}

\begin{abstract}
Wong, F. P., and Midland, S. L. 2007. Sensitivity distributions of California populations of Colletotrichum cereale to the DMI fungicides propiconazole, myclobutanil, tebuconazole, and triadimefon. Plant Dis. 91:1547-1555.

The baseline sensitivity of a California population of Colletotrichum cereale (turfgrass anthracnose) to the sterol demethylation inhibitor (DMI) fungicide propiconazole was determined using an in vitro assay with known reproducibility. The $50 \%$ effective dose $\left(\mathrm{ED}_{50}\right)$ values for propiconazole for a nonexposed, baseline population ranged from 0.025 to $0.35 \mu \mathrm{g} / \mathrm{ml}$ with a mean of $0.14 \mu \mathrm{g} / \mathrm{ml}$. Examination of two DMI-exposed populations indicated an approximate increase of $6.5 \times$ in mean $\mathrm{ED}_{50}$ values. In vivo testing of two isolates with $\mathrm{ED}_{50}$ values of propiconazole at 0.15 and $0.90 \mu \mathrm{g} / \mathrm{ml}$ indicated reduced control for the less sensitive isolate by propiconazole at rates $\leq 38 \mu \mathrm{g} / \mathrm{ml}$. It was determined that single discriminatory dose testing in vitro with propiconazole at $0.50 \mu \mathrm{g} / \mathrm{ml}$ could differentiate sensitive and resistant isolates. Using this dose, six additional populations were tested and DMI-exposed populations were found to be three to nine times less sensitive compared with the baseline population. Two populations were assayed for sensitivity to myclobutanil, tebuconazole, and triadimefon. Mean $\mathrm{ED}_{50}$ values for a nonexposed population were $0.72,0.082$, and $5.6 \mu \mathrm{g} / \mathrm{ml}$, respectively; for a DMI-exposed population, mean $\mathrm{ED}_{50}$ values were $3.8,0.35$, and $18 \mu \mathrm{g} / \mathrm{ml}$, respectively. This work provides information on the development of DMI resistance in populations of C. cereale in California and methodologies for future resistance monitoring for this pathogen.
\end{abstract}

Additional keywords: annual bluegrass, Роа аппиа

Colletotrichum cereale sensu lato Crouch, Clarke, and Hillman (5) is the causal agent of turfgrass anthracnose, a disease that has been increasing in importance for annual bluegrass (Poa апnиа) and creeping bentgrass (Agrostis stolonifera) golf course putting greens. Recently, many superintendents in California, as well as other locations in the United States, reported difficulty in controlling this disease with fungicide spray programs (F. P. Wong, personal observation). As a result of these reports, we suspected that fungicide resistance development in $C$. cereale may be a factor, and undertook several studies to determine the current status of fungicide resistance in California populations of $C$. cereale from golf course locations.

Systemic, single-site mode of action fungicides labeled for turfgrass anthracnose in the United States include the QoIs, benzimidazoles, sterol demethylation inhibitor (DMI) fungicides, and, most recently, the polyoxins and phenylpyrroles.

Corresponding author: F. P. Wong

E-mail: frank.wong@ucr.edu

Accepted for publication 21 June 2007.

doi:10.1094/PDIS-91-12-1547

(C) 2007 The American Phytopathological Society
Recent studies in California have confirmed that resistance to the QoI fungicides (2) is present in a number of locations that have had difficulty controlling the disease (43). Resistance to benzimidazoles also has been reported (7) and is present in California for this pathogen (42). Although DMI fungicides commonly are used in anthracnose management programs, resistance to these fungicides has not been previously examined.

The DMI fungicides (DMIs) are a large subclass of the sterol-biosynthesisinhibiting fungicides that function by disruption of the biosynthesis of ergosterol, a key component of cell membrane structure in most true fungi (kingdom mycota), including ascomycetes, basidiomycetes, chitrydiomycetes, and zygomycetes $(19,21)$. Specifically, the DMIs inhibit the demethylation of lanosterol by a cytochrome P450 lanosterol $14 \alpha$-demethylase, leading to disruption of membrane function by the steric effects of the methylated ergosterol molecules within the cell membrane double-lipid layer (18-21). The DMIs are particularly useful for disease control due to their post-infection activity against fungal plant pathogens (37).

Resistance to DMI fungicides is common for a number of fungal plant pathogens, including Erysiphe graminis, Monilinia fructicola, Mycosphaerella fijiensis, Rhynchosporium secalis, Sphaerotheca fuligenea, Uncinula necator, and Venturia inaequalis (11). Specifically for turf pathogens, DMI resistance has been problematic for Sclerotinia homoeocarpa (dollar spot) $(12,15,28)$. Unlike qualitative resistance, typical for benzimidazole or QoI fungicides $(2,14,18,21)$ where resistant isolates are practically immune to the fungicide, resistance to DMIs is manifested as quantitative resistance, where tolerance develops to these fungicides resulting in the need for the high labeled rate of the fungicide or shortened application intervals to achieve adequate control $(9,22-24,44,45)$.

Myclobutanil, propiconazole, and triadimefon are DMIs registered in the United States for the control of anthracnose caused by $C$. cereale. These were registered for use on turf in California in 1995, 1997, and 1980, respectively. Given the historic use of DMIs for the management of this disease, there is an appreciable risk of DMI-resistance development for C. cereale which should be investigated. Practically, loss of anthracnose control due to DMI-resistance development in $C$. $c e$ reale may not be apparent. Often, DMIs are not used alone in mid- to late-summer when anthracnose is most active due to concerns over detrimental plant growth regulator effects on putting green turf $(1,8,16,30)$. Thus, the use of DMIs early in the season (spring and early summer), limited use in the summer, or use in combination with other fungicides in tank mixes may be hiding practical DMIresistance development for this pathogen.

At the time the study was initiated, propiconazole was the most recently registered DMI fungicide for turf use in California and commonly is used for anthracnose control. Therefore, it was the primary fungicide focused upon. The overall objective of this work was to develop a method to assay for DMI sensitivity, determine the current level of DMI resistance in several populations of $C$. cereale, and assess the potential impact of DMI resistance on anthracnose management programs. Specifically, we intended to (i) determine the baseline sensitivity distribution of $\mathrm{C}$. $\mathrm{ce}$ reale to propiconazole and assess current levels of propiconazole resistance in several field populations of $C$. cereale; (ii) determine if detected shifts in sensitivity to propiconazole were biologically relevant; (iii) use the developed in vitro testing methodology to determine the sensitivity 
of $C$. cereale populations to the additional and tebuconazole, a DMI fungicide currently in late-stage development for use on turf; and (iv) determine levels of crossresistance among these four DMIs.

\section{MATERIALS AND METHODS}

Fungicides. All equipment and chemicals used in this study were obtained from Fisher Scientific (Pittsburgh unless otherwise noted). Technical grade propiconazole (98\% active ingredient; Syngenta, Greensboro, NC), myclobutanil (93\% active; Dow AgroSciences, Indianapolis, IN), tebuconazole (97\% active; Bayer Crop Protection, Kansas City, KS), and triadimefon (95\% active; Bayer Crop Protection) were used for this study. The fungicides were dissolved in acetone to provide stock solutions containing each fungicide at $8.0 \mathrm{mg} / \mathrm{ml}$. All stock solutions were stored at $-20^{\circ} \mathrm{C}$ in $15-\mathrm{ml}$ polystyrene centrifuge tubes sealed with Parafilm.

Collection of $C$. cereale populations. In all, 528 single-conidial isolates of $C$. cereale used in a previous study examining the development of QoI resistance (43) were collected in 2002 through 2004 from nine California golf course locations (Table 1). Two populations, TCGC and SCCC, were collected from annual bluegrass in fairways that were reported to never have been sprayed with DMIs or other fungicides. Typically in California, due to economic limitations and the absence of high humidity conditions and the resulting fungal disease pressure, fungicide applications are not made to fairways or roughs, but rather targeted on putting greens and, to a lesser extent, on greens surrounds, approaches, and tees. Although it was possible for some portion of the population to have been exposed to some DMI fungicides, for the purposes of this study, these populations were considered nonexposed, "baseline" populations. The rest were collected from annual bluegrass putting greens where DMI fungicides had been used routinely for over 10 years (more than three applications per year) and considered "DMI-exposed" populations. DMI fungicides myclobutanil, triadimefon,

Isolates were obtained as described by Wong et al. (43). For baseline populations TCGC and SCCC, samples were collected by randomly gathering $1011-\mathrm{cm}$-diameter plugs of soil and plants using a cup-cutter (Eagle One Golf Products, Anaheim, CA) from areas affected by anthracnose. Sampling was performing using a zigzag sampling strategy with plugs taken at least 10 $m$ apart from each other on each approximate $12,000 \mathrm{~m}^{2}$ fairway area to obtain a diverse sample. For the other populations, three to eight $11-\mathrm{cm}$-diameter plugs were taken from diseased areas on single putting greens (ranging in size from approximately 300 to $600 \mathrm{~m}^{2}$ ). Distribution of sampling points was variable due to the variable distribution in disease development at the locations; however, an attempt was made to take individual samples more than $1 \mathrm{~m}$ apart from each other in order to collect a diverse sample from the location.

Approximately 12 anthracnose-infected plants with sporulating acervuli were taken as broadly as possible from each plug of collected turf. A single conidia was isolated from each plant by placing the infected plant in $300 \mu \mathrm{l}$ of sterile distilled water $\left(\mathrm{sdH}_{2} \mathrm{O}\right)$, streaking the spore suspension on $2 \%$ acidified water agar, and picking off single germinating conidia with a pin aided by a dissecting microscope as described by Wong et al. (43). For the duration of the study, isolates were maintained at $28^{\circ} \mathrm{C}$ on quarter-strength potato dextrose agar (1/4-PDA plates; $9.9 \mathrm{~g}$ of potato dextrose agar and $11.3 \mathrm{~g}$ of granulated agar per liter of $\mathrm{sdH}_{2} \mathrm{O}$ ), with regular transfers to new media at 14-day intervals.

Fungicide sensitivity assays. DMI sensitivity assays were based on methods developed by Wong et al. and Miller et al. $(28,43,44)$. Stock solutions for myclobutanil, propiconazole, and tebuconazole were serially diluted in cold acetone to obtain eight working solutions at fourfold concentrations ranging from 0.00098 to $4.0 \mathrm{mg} / \mathrm{ml}$. Each solution $(1 \mathrm{ml})$ was added to $500 \mathrm{ml}$ of autoclaved and cooled $\left(40^{\circ} \mathrm{C}\right)$ 1/4-PDA to obtain media amended with fungicide at 0.0020 to $8.0 \mu \mathrm{g} / \mathrm{ml}$. For triadimefon, fungicide stocks ranged from

Table 1. Origin and number of Colletotrichum cereale isolates collected in 2002 to 2004 for fungicide sensitivity testing

\begin{tabular}{lllccc}
\hline Population & \multicolumn{1}{c}{ Location } & \multicolumn{1}{c}{ Origin $^{\mathbf{y}}$} & $\begin{array}{c}\text { Exposed to } \\
\text { DMIs }^{\mathbf{z}}\end{array}$ & Isolates & $\begin{array}{c}\text { Collection } \\
\text { date }\end{array}$ \\
\hline AHCC & San Bernardino, CA & Putting green & Yes & 84 & 2002 \\
ANCC & Pasadena, CA & Putting green & Yes & 28 & 2002 \\
FUGC & Fullerton, CA & Putting green & Yes & 65 & 2002 \\
TCGC & Temecula, CA & Fairway & No & 96 & 2002 \\
CLCC & Canyon Lake, CA & Putting green & Yes & 54 & 2003 \\
EGGC & Corona, CA & Putting green & Yes & 60 & 2003 \\
SCCC & San Jose, CA & Fairway & No & 69 & 2003 \\
SHGC & San Bernardino, CA & Putting green & Yes & 40 & 2003 \\
BHCC & Danville, CA & Putting green & Yes & 32 & 2004 \\
Total & . & $\ldots$ & $\ldots$ & 528 & $\ldots$ \\
\hline
\end{tabular}

${ }^{y}$ All isolates were collected from annual bluegrass (Роа апnиа) plants infected with C. cereale.

${ }^{z}$ Demethylation inhibitor fungicides had been used regularly on putting greens locations. No applications were reported to have been made on the fairways sampled in this study.
0.0039 to $16 \mathrm{mg} / \mathrm{ml}$ which were used as described previously to provide a range of media amended with triadimefon at 0.0078 to $32 \mu \mathrm{g} / \mathrm{ml}$. The $0 \mu \mathrm{g} / \mathrm{ml}$ (check) treatment was amended with only $1 \mathrm{ml}$ of acetone. Petri dishes were filled with approximately $20 \mathrm{ml}$ of media per dish in a positivepressure biological safety hood to obtain fungicide-amended 1/4-PDA plates and allowed to solidify overnight. Plates were prepared $24 \mathrm{~h}$ prior to use in fungicide assays.

Assays were performed by inoculating fungicide-amended 1/4-PDA plates with a 5 -mm plug removed from the edge of a 7day-old culture of $C$. cereale grown on 1/4-PDA as described above. Plugs were placed onto the center of the agar with the plug inverted so that the top side of the plug was in direct contact with the fungicide-amended media. For each isolate, seven fungicide concentrations were used in addition to the nonfungicide-amended check plate. Plates were incubated for 7 days at $28^{\circ} \mathrm{C}$ without supplemental lighting, and then radial growth was measured by taking the average of three colony diameter measurements, subtracting the size of the original plug used for inoculation, and dividing by two.

Fungicide sensitivity, as measured by the $50 \%$ effective dose $\left(\mathrm{ED}_{50}\right)$, was calculated as described by Wong and Wilcox (44). Briefly, the percent relative growth (RG) was calculated as (radial growth at fungicide concentration/radial growth on the nonamended check plate) $\times 100$. RG values were plotted against the log fungicide concentration and regression performed through the linear portion of the dose response using Microsoft Excel (Redmond, WA). The $\log \mathrm{ED}_{50}$ was calculated based upon the x-intercept corresponding to an $\mathrm{RG}$ value of 50 ; $\mathrm{ED}_{50}$ values were calculated by taking the antilog of the calculated $\log \mathrm{ED}_{50}$ value.

Assay reproducibility. To determine the reproducibility and variance inherent in a single test, the sensitivity assay was performed using five isolates of $C$. cereale from the baseline population TCGC which were tested five times using new stock solutions each time. Variance, coefficients of variance, and upper and lower 95\% confidence intervals were calculated using the normally distributed $\log \mathrm{ED}_{50}$ values as described previously (44). Assay reproducibility was examined only for propiconazole.

Distributions of C. cereale sensitivities to propiconazole. After establishing test reproducibility, 96 isolates from the baseline population TCGC were tested using the full range of fungicide concentrations. Histograms were constructed using log $\mathrm{ED}_{50}$ classes based upon the least significant difference (LSD; $\alpha=0.05$ ) between the five isolates tested five times for assay reproducibility (approximately $0.5 \quad \mathrm{log}$ units). In all, 84 isolates from AHCC and 
65 from FUGC, both DMI-exposed populations, also were tested in the same manner to compare the distribution of sensitivities from a baseline population and exposed population. Population $\log \mathrm{ED}_{50}$ means were compared using $t$ tests (Microsoft Excel).

In vivo sensitivity of two $\mathrm{C}$. cereale isolates to propiconazole. An isolate from the baseline population (TCGC-5.2, $\mathrm{ED}_{50}$ of propiconazole $=0.15 \mu \mathrm{g} / \mathrm{ml})$ and one from the exposed population (AHCC-1, ED ${ }_{50}$ of propiconazole $=0.90 \mu \mathrm{g} / \mathrm{ml})$ were used to inoculate greenhouse-grown annual bluegrass ( $P$. annua 'True-putt'; DLF International, Halsey, OR) treated preventively with propiconazole. Plants were seeded at the rate of $19 \mathrm{~g} / \mathrm{m}^{2}$ in University of California soil-less mix (UC Mix) in 7.5-cmdiameter plastic pots and grown for 6 weeks before inoculation. Plants were maintained at ambient greenhouse conditions (approximately 20 to $30^{\circ} \mathrm{C}$ ), clipped at a height of $5 \mathrm{~cm}$ once per week, and watered as needed. Plants were inoculated with a spore suspension of conidia from either isolate TCGC-5.2 or AHCC-1 with a $\mathrm{CO}_{2}$-powered sprayer as described above until run off. Isolates were grown for 14 days on 1/4-PDA at $28^{\circ} \mathrm{C}$ and conidia harvested by flooding the plates with $\mathrm{sdH}_{2} \mathrm{O}$. The suspension was filtered through a double layer of cheesecloth and adjusted to a final concentration of $1 \times 10^{6}$ conidia $/ \mathrm{ml}$. Plants were covered with plastic bags for $48 \mathrm{~h}$ and incubated at $35^{\circ} \mathrm{C}$ and $80 \%$ relative humidity with $12 \mathrm{~h}$ of fluorescent light in a growth chamber (GC15; Environmental Growth Chambers, Chagrin Falls, $\mathrm{OH})$.

Bags then were removed and treated with propiconazole (Banner MAXX; Syngenta) at the equivalent of $0,2.4,9.6,38$, 150 , or $610 \mu \mathrm{g} / \mathrm{ml}$ applied until run-off with a $\mathrm{CO}_{2}$-powered sprayer using a single TeeJet 8002VS nozzle (R\&D Sprayers, Opelousas, LA) at a pressure of $2.0 \mathrm{~atm}$. Three pots of plants were used per experimental treatment. Plants were maintained in the chambers for an additional 12 days with daily misting, and disease severity scored for each pot at this time, rating plants on a linear 0 -to-10 scale with 0 equal to no symptoms, $5=50 \%$ of the plants showing symptoms, and $10=100 \%$ of the plants showing symptoms. Assays were performed separately for the two isolates. Three pots were used for each fungicide concentration and the test was performed three times. Severity data were normalized using an arcsine (y) transformation where $y=$ severity rating/10. For each isolate, means of the treatments were analyzed by analysis of variance (ANOVA) and compared using Fisher's Protected LSD with $\alpha=0.05$.

Single discriminatory dose monitoring of C. cereale populations for sensitivity to propiconazole. Single discriminatory dose testing for fungicide sensitivity can be utilized to monitor for population shifts in sensitivity and estimate $\mathrm{ED}_{50}$ values as described for pathogens such as $V$. inaequalis and $U$. necator $(35,44)$. Calculated $\log \mathrm{ED}_{50}$ values were regressed against $\mathrm{RG}$ values for individual isolates from populations AHCC, FUGC, and TCGC. Significance and coefficients of determination $\left(R^{2}\right)$ were calculated for the relationships at all concentrations (SAS 9.1, Cary, NC). Based on the correlation analysis, it was determined that the single discriminatory dose of propiconazole at $0.50 \mu \mathrm{g} / \mathrm{ml}$ would be most effective. A linear equation describing the relationship was calculated in order to estimate $\log$ $\mathrm{ED}_{50}$ values for propiconazole based upon the RG values for isolates assayed with propiconazole at $0.50 \mu \mathrm{g} / \mathrm{ml}$. The remaining isolates from populations ANCC, BHCC, CLCC, EGGC, SCCC, and SHGC were tested once with propiconazole at 0.50 and $0 \mu \mathrm{g} / \mathrm{ml}$; RG was measured as described above and used to construct sensitivity distribution histograms in MSExcel and to estimate isolate $\log \mathrm{ED}_{50}$ values for propiconazole.

Sensitivity of C. cereale isolates to myclobutanil, tebuconazole, and triadimefon. $\mathrm{ED}_{50}$ values for a subset of 58 isolates from baseline population TCGC and 60 from DMI-exposed population AHCC were determined for myclobutanil, tebuconazole, and triadimefon using the methodology described above. Isolates were tested against a range of seven fungicide concentrations and a nonamended check treatment. For each population and fungicide, sensitivity distribution histograms were constructed using the $\log \mathrm{ED}_{50}$ values. Mean $\log \mathrm{ED}_{50}$ values for each population to the three fungicides were analyzed and compared using ANOVA and Fisher's protected LSD (SAS 9.1), whereas mean $\log \mathrm{ED}_{50}$ values for the same fungicide between populations AHCC and TCGC were compared using two-tailed $t$ tests with $\alpha=0.05$. Crosssensitivity among fungicides was performed by regression analysis, comparing myclobutanil, propiconazole, tebucona$\log \mathrm{ED}_{50}$ values for individual isolates for

zole, and triadimefon (SAS 9.1). The relationship among the individual populations TCGC and AHCC were analyzed separately as well as together to determine the relationships between sensitivity values for all six possible correlations between the four fungicides.

\section{RESULTS}

Fungicide assay results. Assay reproducibility. Based upon the five isolates assayed independently five times, it appeared that there was high reproducibility in determining $\log \mathrm{ED}_{50}$ values for propiconazole using the assay. The average coefficient of variance was $0.22 \%$, with a range of 0.36 to $0.025 \%$ (Table 2), reflecting a high amount of reproducibility for this assay.

Distributions of $\mathrm{C}$. cereale sensitivities to propiconazole. For the baseline population TCGC, $\mathrm{ED}_{50}$ values ranged from propiconazole at 0.025 to $0.35 \mu \mathrm{g} / \mathrm{ml}$ with a mean of $0.14 \mu \mathrm{g} / \mathrm{ml}$ (Fig. 1, Table 3). Comparatively, $\mathrm{ED}_{50}$ values for the two DMI-exposed populations ranged from propiconazole at 0.22 to $1.5 \mu \mathrm{g} / \mathrm{ml}$ with means of 0.91 and $0.97 \mu \mathrm{g} / \mathrm{ml}$ for populations AHCC and FUGC, respectively (Fig. 1 , Table 3 ). These results indicated a clear shift in sensitivities between the baseline and DMI-exposed populations, in the range of 6.5- to 6.7-fold with respect to shifts in mean $\mathrm{ED}_{50}$ values.

In vivo sensitivity of two $\mathrm{C}$. cereale isolates to propiconazole. For isolates TCGC$5.2\left(\mathrm{ED}_{50}=0.15 \mu \mathrm{g} / \mathrm{ml}\right)$ and AHCC-1 $\left(\mathrm{ED}_{50}=0.90 \mu \mathrm{g} / \mathrm{ml}\right)$, both isolates were controlled fully at propiconazole concentrations of 150 and $610 \mu \mathrm{g} / \mathrm{ml}$ (Fig. 2). For TCGC-5.2, treatment with propiconazole at $38,9.8,2.4$, and $0.60 \mu \mathrm{g} / \mathrm{ml}$ resulted in $100,92,77$, and $19 \%$ control, respectively, relative to the $0 \mu \mathrm{g} / \mathrm{ml}$ check treatment. For AHCC-1, the same concentration range provided only $82,51,18$, and $1.8 \%$ control, respectively, relative to the $0 \mu \mathrm{g} / \mathrm{ml}$ check treatment, indicating a differential response between isolates with differing $\mathrm{ED}_{50}$ values in vivo (Fig. 2).

Distributions of $\mathrm{C}$. cereale sensitivities to propiconazole based upon single dis-

Table 2. Assay reproducibility for determining $50 \%$ effective dose $\left(\mathrm{ED}_{50}\right)$ values for propiconazole for Colletotrichum cereale using mycelial expansion measurements on fungicide amended quarterstrength potato dextrose agar

\begin{tabular}{lccccc}
\hline Isolate & Mean $(\boldsymbol{\mu g} / \mathbf{m l})^{\mathrm{v}}$ & $\mathbf{9 5 \%} \mathbf{L L}^{\mathrm{w}}$ & $\mathbf{9 5 \%} \mathbf{U L}^{\mathrm{x}}$ & Variance $^{\mathrm{y}}$ & $\mathbf{C V}(\boldsymbol{\%})^{\mathrm{z}}$ \\
\hline TCGC-5.30 & 0.100 & 0.046 & 0.27 & 0.00036 & 0.36 \\
TCGC-5.1 & 0.058 & 0.026 & 0.15 & 0.000067 & 0.11 \\
TCGC-5.25 & 0.054 & 0.024 & 0.14 & 0.000032 & 0.058 \\
TCGC-8.11 & 0.057 & 0.028 & 0.29 & 0.000014 & 0.025 \\
TCGC-8.20 & 0.089 & 0.041 & 0.24 & 0.00048 & 0.53 \\
Average & $\ldots$ & $\ldots$ & $\ldots$ & 0.00019 & 0.22 \\
\hline
\end{tabular}

${ }^{v}$ Mean $\mathrm{ED}_{50}$ value based upon $\log \mathrm{ED}_{50}$ values obtained from five repeated assays, isolates grown for 7 days at $28^{\circ} \mathrm{C}$ on propiconazole-amended media.

${ }^{w}$ Lower $95 \%$ confidence interval based upon $\log \mathrm{ED}_{50}$ values.

${ }^{x}$ Upper $95 \%$ confidence interval based upon $\log \mathrm{ED}_{50}$ values.

y Variance based upon $\log \mathrm{ED}_{50}$ values.

${ }^{\mathrm{z}}$ Coefficient of variance based upon $\log \mathrm{ED}_{50}$ values. 
criminatory dose testing. For determining the best correlation between the RG values for growth with propiconazole at 0.0020 , $0.0078,0.031,0.13,0.50,2.0$, and 8.0 $\mu \mathrm{g} / \mathrm{ml}$ and calculated $\log \mathrm{ED}_{50}$ values, using all of the isolates from TCGC, AHCC, and FUGC, the best linear relationship was determined to be for RG with propiconazole at $0.50 \mu \mathrm{g} / \mathrm{ml}$ (Fig. 3). The relationship was described by the function $\log \mathrm{ED}_{50}=0.015 \times(\mathrm{RG})-1.1$, with $R^{2}=$ 0.92 and $P<0.001$. Using this relationship, single discriminatory dose testing with propiconazole at $0.50 \mu \mathrm{g} / \mathrm{ml}$ would estimate $\mathrm{ED}_{50}$ values of 0.079 to $2.5 \mu \mathrm{g} / \mathrm{ml}$ based upon RG values of 0 to 100 obtained by this test.

For histograms constructed based on the $\mathrm{RG}$ values from the $348 C$. cereale isolates from populations ANGC, BHCC, CLCC, EGGC, SCCC, and SHGC, there was a clear differentiation between the baseline populations (TCGC and SCCC) and the remaining DMI-exposed populations (Fig. 4). The RG values obtained from DMIexposed populations generally were outside of the range of RG values obtained for the baseline isolates (Table 4). Based on the estimated $\log \mathrm{ED}_{50}$ values for propiconazole, the mean values for the baseline populations TCGC and SCCC were roughly equivalent $(0.14$ and $0.18 \mu \mathrm{g} / \mathrm{ml}$, respectively). Estimated mean $\log \mathrm{ED}_{50}$ values from the DMI-exposed populations were 4.3 to 8.1 times higher compared with the combined mean of the two baseline populations (Table 4).

Sensitivity distributions of C. cereale isolates to myclobutanil, tebuconazole, and triadimefon. For the 58 isolates from baseline population TCGC, there were significant differences among calculated log $\mathrm{ED}_{50}$ distributions for myclobutanil, tebuconazole, and triadimefon (Fig. 5A; Table 5). Mean $\log \mathrm{ED}_{50}$ values were significantly different amongst the four fungi-

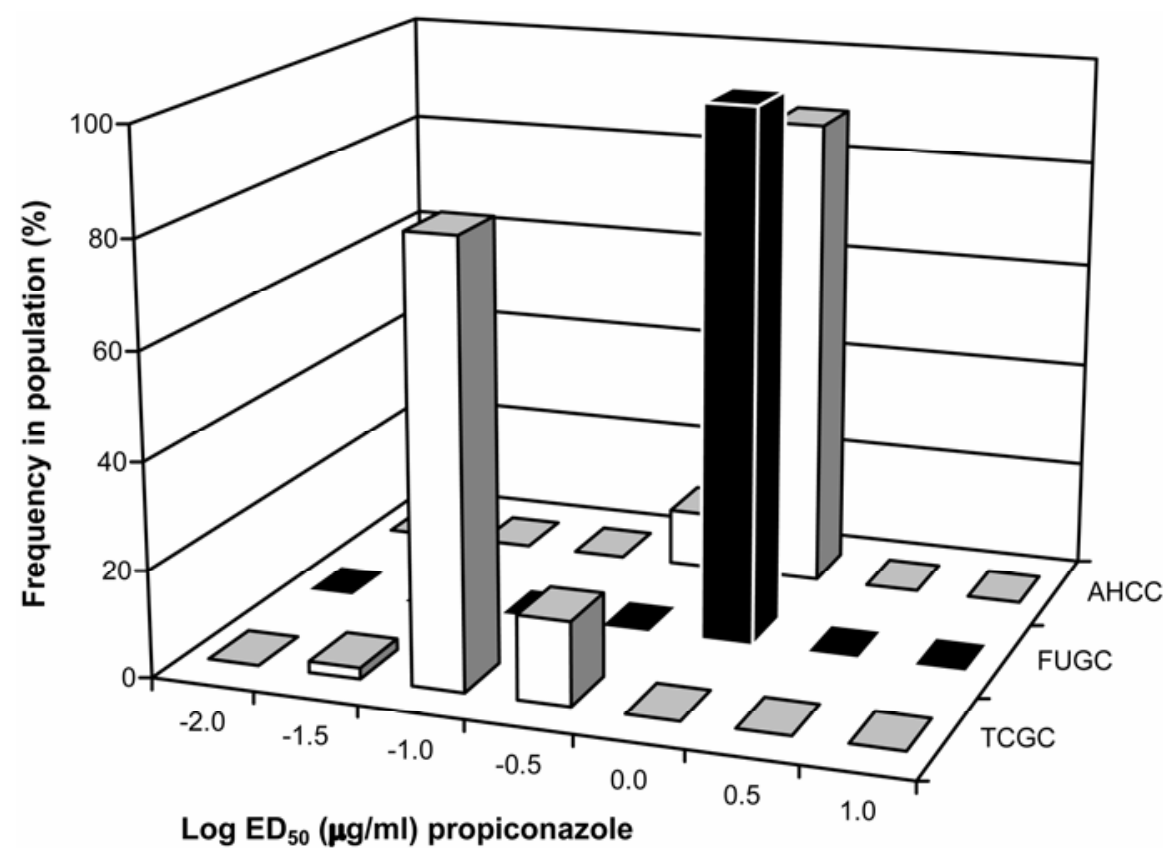

Fig. 1. Frequency distributions of sensitivities of three Colletotrichum cereale populations to propiconazole based upon bioassays using quarter-strength potato dextrose agar amended with propiconazole at a concentration range of 0.0 to $8.0 \mu \mathrm{g} / \mathrm{ml}$. Population TCGC $(n=96)$ is a baseline population and AHCC $(n=84)$ and FUGC $(n=65)$ are fungicide-exposed populations. X-axis values represent the midpoint of each histogram class, with histogram classes based upon the calculated Fisher's least significant difference value of $0.5 \log$ units $(\alpha=0.053)$ for calculated $50 \%$ effective dose $\left(E_{50}\right)$ values of five isolates based upon five repeated tests.

Table 3. Sensitivity distributions of populations of Colletotrichum cereale to propiconazole

\begin{tabular}{lcccl}
\hline & & \multicolumn{3}{c}{$\mathbf{E D}_{\mathbf{5 0}}(\boldsymbol{\mu g} / \mathbf{m l})$ propiconazole $^{\mathbf{z}}$} \\
\cline { 3 - 5 } Population & $\boldsymbol{n}$ & Min & Mean & Max \\
\hline AHCC (exposed) & 84 & 0.22 & $0.91 \mathrm{~b}$ & 1.5 \\
FUGC (exposed) & 65 & 0.64 & $0.97 \mathrm{~b}$ & 1.5 \\
TCGC (baseline) & 96 & 0.025 & $0.14 \mathrm{a}$ & 0.35 \\
\hline
\end{tabular}

${ }^{\mathrm{z}} \log 50 \%$ effective dose $\left(\mathrm{ED}_{50}\right)$ calculated by measuring radial growth of isolates on propiconazoleamended quarter-strength potato dextrose agar; relative growth was plotted versus the log concentration of fungicide and regression performed through the linear portion of the dose response to calculate $\mathrm{ED}_{50}$ values. Values here represent the anti-log of the calculated values. Min and Max = minimum and maximum, respectively. Means followed by the same letter are equivalent, based on onetailed $t$ tests with $\alpha=0.05$. cides (ANOVA, $P<0.001$ ), with the mean $\mathrm{ED}_{50}$ value for tebuconazole being the lowest $(0.082 \mu \mathrm{g} / \mathrm{ml})$, followed by propiconazole $(0.14 \mu \mathrm{g} / \mathrm{ml})$, myclobutanil $(0.72$ $\mu \mathrm{g} / \mathrm{ml})$, and triadimefon $(5.6 \mu \mathrm{g} / \mathrm{ml})$.

For population AHCC, mean log $\mathrm{ED}_{50}$ values were significantly different for the four fungicides (ANOVA, $P<0.001$ ), with the mean $\mathrm{ED}_{50}$ value for tebuconazole being the lowest $(0.35 \mu \mathrm{g} / \mathrm{ml})$, followed by propiconazole $(0.82 \mu \mathrm{g} / \mathrm{ml})$, myclobutanil $(3.8 \mu \mathrm{g} / \mathrm{ml})$, and triadimefon $(18 \mu \mathrm{g} / \mathrm{ml})$ (Fig. 5B; Table 5).Although $\mathrm{ED}_{50}$ values for exposed population AHCC were higher compared with baseline population TCGC, the relative differences in sensitivity to the four fungicides was similar.

Cross-sensitivity among myclobutanil, propiconazole, tebuconazole, and triadimefon for isolates of $\mathrm{C}$. cereale. For the regression analysis performed for the six interactions between the four fungicides, the relationship between sensitivities for the fungicides within the baseline population TCGC was moderate, and poor for the less sensitive isolates from DMI-exposed population AHCC (Table 6). For population TCGC, the linear regression analysis indicated $P$ values were lowest for the interactions of triadimefon-myclobutanil, tebuconazole-propiconazole, triadimefontebuconazole, and myclobutanil-tebuconazole $(P<0.0034) . R^{2}$ values ranged from 0.21 to 0.34 for these interactions, indicating a low amount of dependence between sensitivities for these fungicides. For the correlation between $\log \mathrm{ED}_{50}$ values for propiconazole-myclobutanil and propiconazole-triadimefon, $P=0.13$ and 0.054 , respectively, and $R^{2}$ values for these interactions were 0.065 or less. For population AHCC, for all but the interaction of triadimefon-propiconazole, regression analysis indicated nonsignificant $P$ values $(P \geq$ 0.32 ). For the interaction of triadimefonpropiconazole, $P=0.0092$, but the $R^{2}$ value was 0.11 .

When the $\log \mathrm{ED}_{50}$ values from all of the isolates from both populations were pooled and analyzed together, all interactions were shown to have $P<0.001$. The correlation between myclobutanil-propiconazole, tebuconazole-propiconazole, and myclobutanil-tebuconazole were strong, as reflected by $R^{2}$ values of $0.75,0.73$, and 0.78 , respectively (Table 6; Fig. 6). Correlation between the $\log \mathrm{ED}_{50}$ values of the remaining fungicide combinations (triadimefon-myclobutanil, triadimefon-propiconazole, and triadimefon-tebuconazole) were lower, with $R^{2}$ ranging between 0.48 and 0.58 .

\section{DISCUSSION}

In this work, we present information on methods for monitoring $C$. cereale sensitivities to propiconazole, evidence for shifts in sensitivity for this fungicide that already have occurred at locations where DMIs have been used regularly, and evi- 
dence for cross-sensitivity among four DMI fungicides. This is the first published baseline sensitivity distribution for DMIs for $C$. cereale and the information and methods presented here should allow for future monitoring for DMI resistance for this pathogen and implementation of resistance management strategies for this pathogen.

The method developed here to determine $\mathrm{ED}_{50}$ values for propiconazole had a high amount of reproducibility similar to other systems studied $(28,44)$, based on independently performed replicated tests on five isolates. This method also appeared applicable for the determination of $\mathrm{ED}_{50}$ values for myclobutanil, tebuconazole, and triadimefon. An abbreviated form of the assay using a single discriminatory dose of propiconazole at $0.50 \mu \mathrm{g} / \mathrm{ml}$ was able to differentiate between isolates with $\mathrm{ED}_{50}$ values equivalent to baseline population isolates and those with reduced sensitivity to propiconazole.

With regard to the baseline sensitivity distribution to propiconazole, the $14 \times$ range of $\mathrm{ED}_{50}$ values was similar compared with those determined for propiconazole for Sclerotinia homoeocarpa (28) and Cercospora beticola (17) and unlike the broader range $(100 \times$ to $950 \times)$ observed for propiconazole sensitivity distributions for pathogens such as Cladosporium caryigenum (31), Monilinia fructicola (33), $M$. oxycocci (27), and Mycosphaerella fijiensis (32) or other DMIs for U. necator $(9,44,45)$ and $V$. inaequalis $(23,24,35)$. Shifts in propiconazole sensitivity as measured by the ratio of the mean $\mathrm{ED}_{50}$ value of exposed population were similar to what was observed for other pathogens where practical resistance had developed to this fungicide $(28,32)$. Although there is no prior work examining the effects of sensitivity shifts in Colletotrichum cereale populations to propiconazole, mean sensitivity shifts of roughly eight times observed for $U$. necator and $V$. inaequalis were associated with the development of practical resistance to myclobutanil $(23,44)$.

In vivo tests with two isolates with a six times difference in propiconazole sensitivity did indicate a differential response to curative applications of propiconazole. Curative treatments were chosen because DMI fungicides typically have no protectant effect on spore germination and initial tissue colonization (37). Differences in disease control between these two isolates were seen only at concentrations of propiconazole at or below $38 \mu \mathrm{g} / \mathrm{ml}$, approximately $1 / 16$ the labeled rate of the fungicide. This response was similar to what was seen for the control of $V$. inaequalis isolates with differing sensitivities to myclobutanil (24). This implies that isolates that were in this range of decreased sensitivity are less controlled by fungicide applications and could be considered resis- tant. Practically, the impact of these shifts could be minimal due to the high rate at which fungicides are used on turfgrass. Propiconazole is labeled for anthracnose control on golf course putting greens at rates of 496 to $993 \mathrm{~g} / \mathrm{ha}$. Comparatively, propiconazole typically is applied on a range of agronomic and horticultural crops at rates of approximately 94 to $190 \mathrm{~g} / \mathrm{ha}$. As a result, $C$. cereale populations are exposed to a relatively high dose of propiconazole, which is able to provide adequate control of both sensitive and "resistant" populations. The use of such a high-

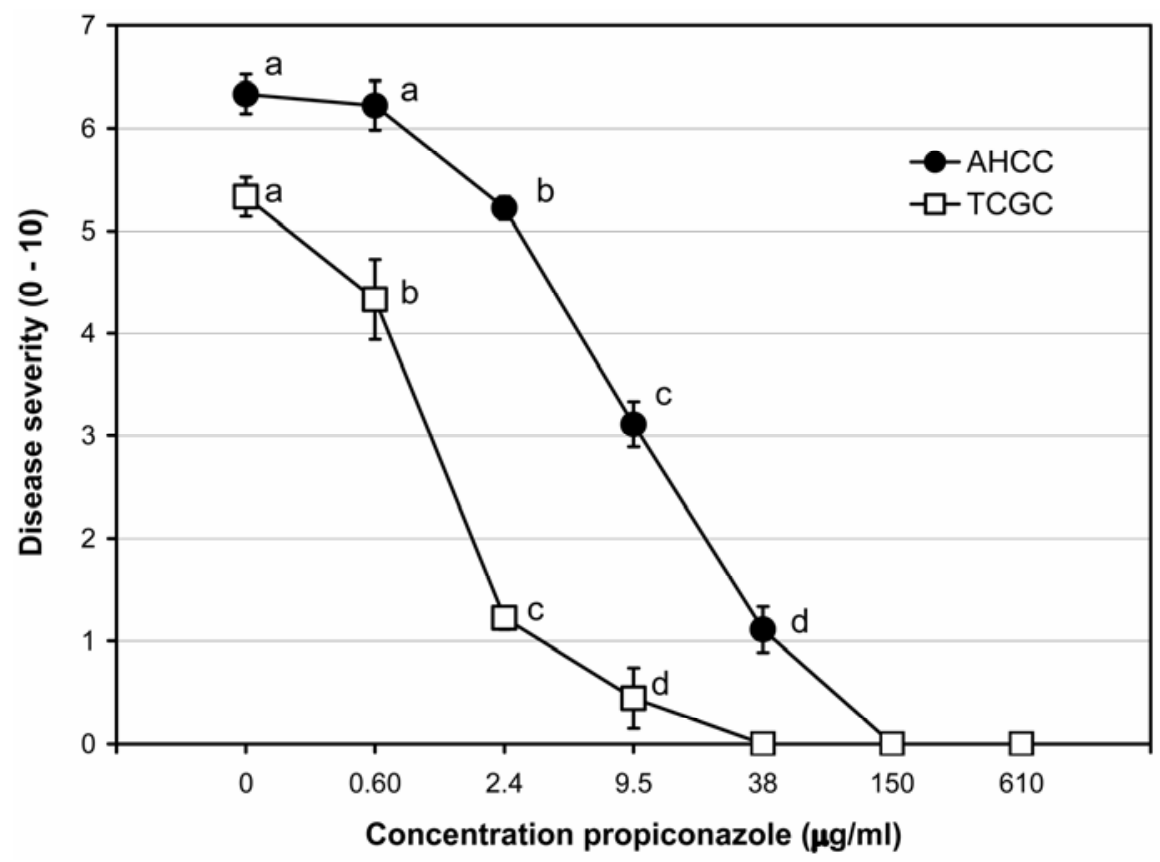

Fig. 2. Control of two Colletotrichum cereale isolates, TCGC-5.2 (baseline population isolate, propiconazole $50 \%$ effective dose $\left[\mathrm{ED}_{50}\right]=0.15 \mu \mathrm{g} / \mathrm{ml}$ ) and AHCC-1 (exposed population isolate, propiconazole $\mathrm{ED}_{50}=0.90 \mu \mathrm{g} / \mathrm{ml}$ ), with propiconazole in vivo. Six-week-old annual bluegrass grown in 7.5$\mathrm{cm}$ plastic pots were treated with propiconazole at $0,0.60,2.4,9.8,38,150$, or $610 \mu \mathrm{g} / \mathrm{ml} 48 \mathrm{~h}$ after inoculation with a conidial suspension of either isolate TCGC-5.2 or AHCC-1. Plants were rated 14 days after inoculation for disease development on a linear 0 -to- 10 scale, where $0=$ no plants showing symptoms, $5=50 \%$ of the plants showing symptoms, and $10=100 \%$ of the plants showing symptoms. Points reflect the means of three tests using three replicates per treatment, and error bars reflect the standard error of the mean. For each isolate, means designated with the same letter are statistically equivalent (Fisher's protected least significant difference, $\alpha=0.05$ ).

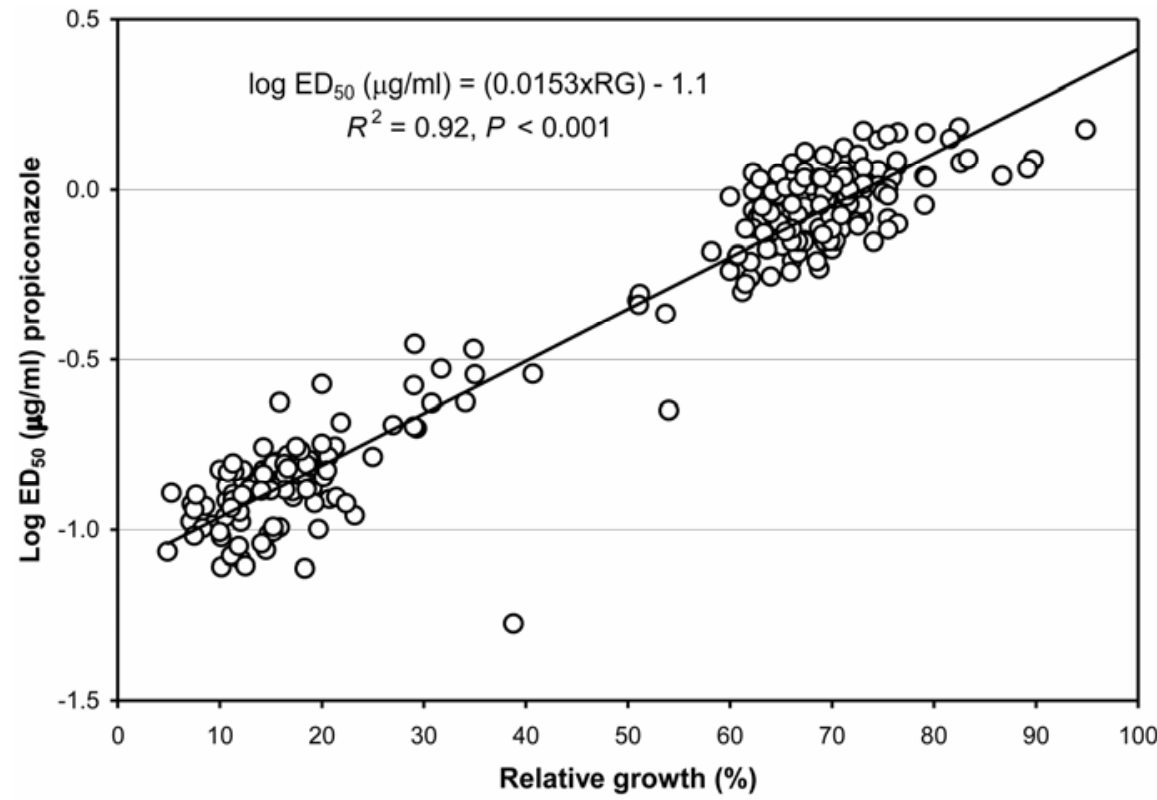

Fig. 3. Correlation between percent relative growth $(\mathrm{RG})$ at the discriminatory dose of propiconazole at $0.50 \mu \mathrm{g} / \mathrm{ml}$ and actual calculated $\log 50 \%$ effective dose $\left(\mathrm{ED}_{50}\right)(\mu \mathrm{g} / \mathrm{ml}$ propiconazole) values for 245 isolates of Colletotrichum cereale from three populations. The relationship is useful as an estimate of $\mathrm{ED}_{50}$ values based upon single discriminatory dose testing of isolates. 
rate strategy for DMI fungicides has been proposed by Köller and Wilcox. (20,23); however, for most agricultural systems, such rates would be unpractical or cost prohibitive. This is not the case for fungi- cide applications to golf course putting greens.

In examining recent results from university field trials with propiconazole, results are mixed as far as season-long control.

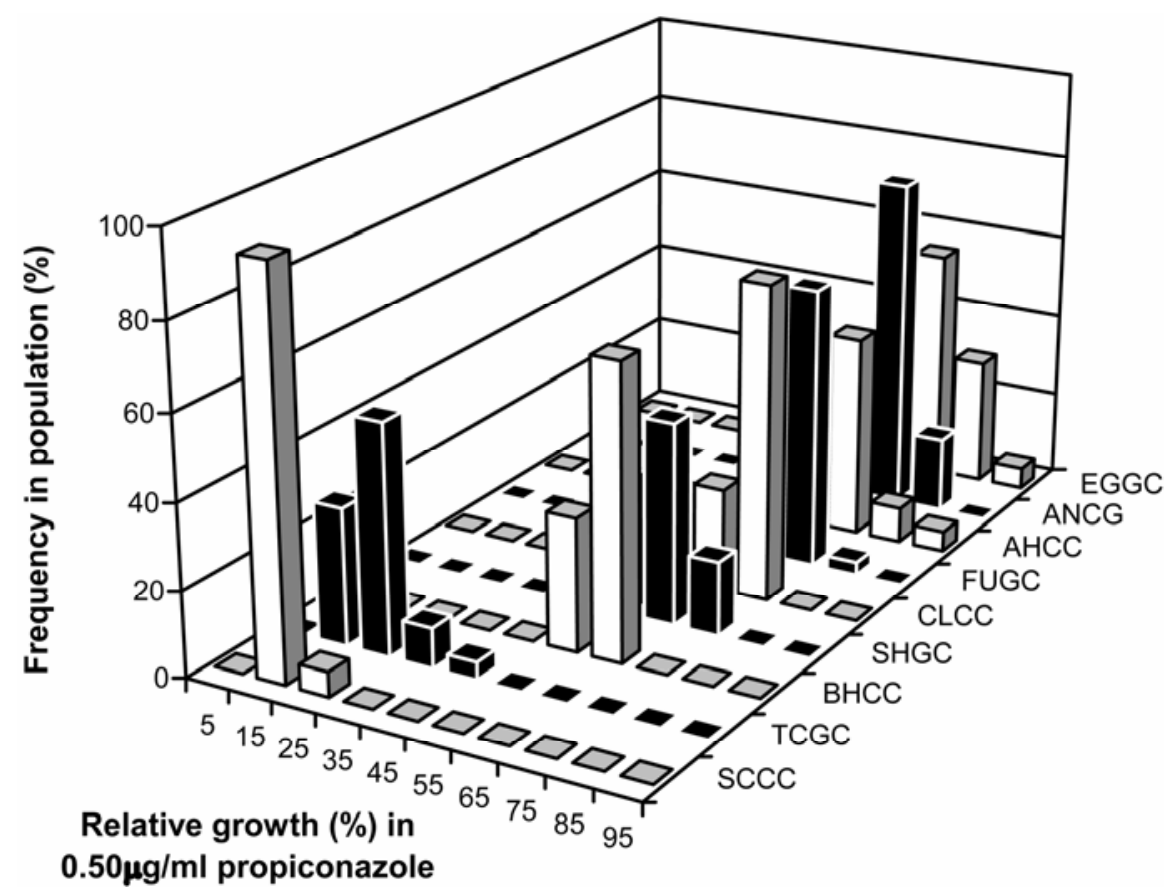

Fig. 4. Frequency distributions of sensitivities of nine Colletotrichum cereale populations to propiconazole based upon percent relative growth of isolates tested at the single discriminatory dose of propiconazole at $0.50 \mu \mathrm{g} / \mathrm{ml}$. Populations TCGC and SCCC are baseline populations, whereas the remainder are demethylation inhibitor fungicide exposed. $\mathrm{X}$-axis values represent the midpoint of each histogram class.
For example, in 2002 Pennsylvania and 2004 Georgia trials, applications of propiconazole at 240 to $993 \mathrm{~g} / \mathrm{ha}$ provided only 20 to $0 \%$ control in season-long programs $(4,39,40)$. In other locations, such as field trials conducted in New Jersey in 2002 (38) and Pennsylvania in 2003 (41), applications provided 91 to $100 \%$ control. Furthermore, there were a number of locations in California, Pennsylvania, and Georgia $(3,10,13,26)$ where labeled rates of propiconazole provided control ranging from 65 to $84 \%$ in season-long programs. In these cases, the sensitivity of the $C$. cereale populations to propiconazole was not examined, and the role of sensitivity shifts is not understood as far as its contribution to the variable results that were seen in these field trials. There is a possibility that some detrimental plant growth regulator effects caused by propiconazole (30) under warm temperature conditions to the turf could have contributed to the apparent damage reported in some of these trials. This lack of information mandates a further examination to determine what magnitudes of sensitivity shifts actually confer practical resistance (18).

In examining cross-sensitivity among propiconazole, myclobutanil, tebuconazole, and triadimefon, results were similar to those reported for other pathogens such as $S$. homoeocarpa $(15,28)$, Cercospora beticola (17), and $U$. necator $(9,45)$. When the baseline population TCGC and exposed population AHCC were analyzed separately, coefficients of correlation gen-

Table 4. Comparison of Colletotrichum cereale population sensitivities to propiconazole based on single discriminatory dose testing with propiconazole at $0.50 \mu \mathrm{g} / \mathrm{ml}$

\begin{tabular}{|c|c|c|c|c|c|c|c|}
\hline \multirow[b]{2}{*}{ Population } & \multirow[b]{2}{*}{$n$} & \multicolumn{3}{|c|}{ RG with propiconazole at $0.50 \mu \mathrm{g} / \mathrm{ml}^{\mathrm{y}}$} & \multicolumn{3}{|c|}{ 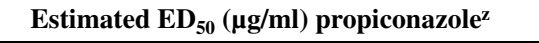 } \\
\hline & & Mean & Minimum & Maximum & Mean & Minimum & Maximum \\
\hline $\mathrm{AHCC}$ & 84 & 71 & 55 & 100 & 0.98 & 0.53 & 2.6 \\
\hline ANCG & 28 & 77 & 64 & 90 & 1.2 & 0.73 & 1.8 \\
\hline $\mathrm{BHCC}$ & 32 & 62 & 51 & 70 & 0.68 & 0.46 & 0.90 \\
\hline CLCC & 54 & 72 & 50 & 79 & 0.98 & 0.45 & 1.2 \\
\hline EGGC & 60 & 78 & 35 & 96 & 1.3 & 0.27 & 2.3 \\
\hline FUGC & 65 & 72 & 64 & 81 & 0.97 & 0.74 & 1.3 \\
\hline SCCC & 69 & 18 & 14 & 20 & 0.14 & 0.13 & 0.16 \\
\hline SHGC & 40 & 63 & 50 & 79 & 0.74 & 0.45 & 1.26 \\
\hline TCGC & 96 & 24 & 13 & 45 & 0.18 & 0.12 & 0.38 \\
\hline
\end{tabular}

${ }^{y} \mathrm{RG}=$ relative growth. Percent growth relative to the nonamended check treatment for isolates grown for 7 days on quarter-strength potato dextrose agar amended with propiconazole at $0.50 \mu \mathrm{g} / \mathrm{ml}$.

${ }^{\mathrm{z}}$ Calculated based on the formula $\log 50 \%$ effective dose $\left(\mathrm{ED}_{50}\right)(\mu \mathrm{g} / \mathrm{ml})=(0.0153 \times \mathrm{RG})-1.1$, as determined by regression analysis of actual calculated $\log \mathrm{ED}_{50}$ values versus $\mathrm{RG}$ at a dose of propiconazole at $0.50 \mu \mathrm{g} / \mathrm{ml}$.

Table 5. Sensitivity of two Colletotrichum cereale populations to myclobutanil, propiconazole, tebuconazole, and triadimefon

\begin{tabular}{|c|c|c|c|c|c|c|c|c|c|}
\hline \multirow[b]{3}{*}{ Fungicide } & \multicolumn{8}{|c|}{$\mathbf{E D}_{50}(\mu \mathrm{g} / \mathrm{ml})^{y}$} & \multirow[b]{3}{*}{$P(t \text { test })^{\mathrm{z}}$} \\
\hline & \multicolumn{4}{|c|}{ TCGC (baseline, $n=58$ ) } & \multicolumn{4}{|c|}{ AHCC $(\operatorname{exposed}, n=60)$} & \\
\hline & Mean & Min & Max & Range & Mean & Min & Max & Range & \\
\hline Myclobutanil & $0.72 \mathrm{~b}$ & 0.19 & 1.3 & 7.2 & $3.8 \mathrm{~b}$ & 2.0 & 11 & 5.4 & $<0.001$ \\
\hline Propiconazole & $0.14 \mathrm{c}$ & 0.053 & 0.35 & 6.6 & $0.82 \mathrm{c}$ & 0.22 & 1.5 & 6.9 & $<0.001$ \\
\hline Tebuconazole & $0.082 \mathrm{~d}$ & 0.015 & 0.57 & 38 & $0.35 \mathrm{~d}$ & 0.19 & 0.70 & 3.6 & $<0.001$ \\
\hline Triadimefon & $5.6 \mathrm{a}$ & 2.2 & 13 & 5.9 & $18 \mathrm{a}$ & 5.5 & 64 & 12 & $<0.001$ \\
\hline
\end{tabular}

${ }^{\text {y }}$ Calculations performed using the $\log 50 \%$ effective dose $\left(\mathrm{ED}_{50}\right)$ values calculated from dose responses on quarter-strength potato dextrose agar amended with fungicides; values reflect the anti-log of the calculated values. Min and Max = minimum and maximum, respectively. Means within columns followed by the same letter are equivalent based on Fisher's protected least significant difference $(\alpha=0.05)$.

${ }^{\mathrm{z}} P$ value for a one-tailed $t$ test comparing the means of populations AHCC and TCGC for the same fungicide. 

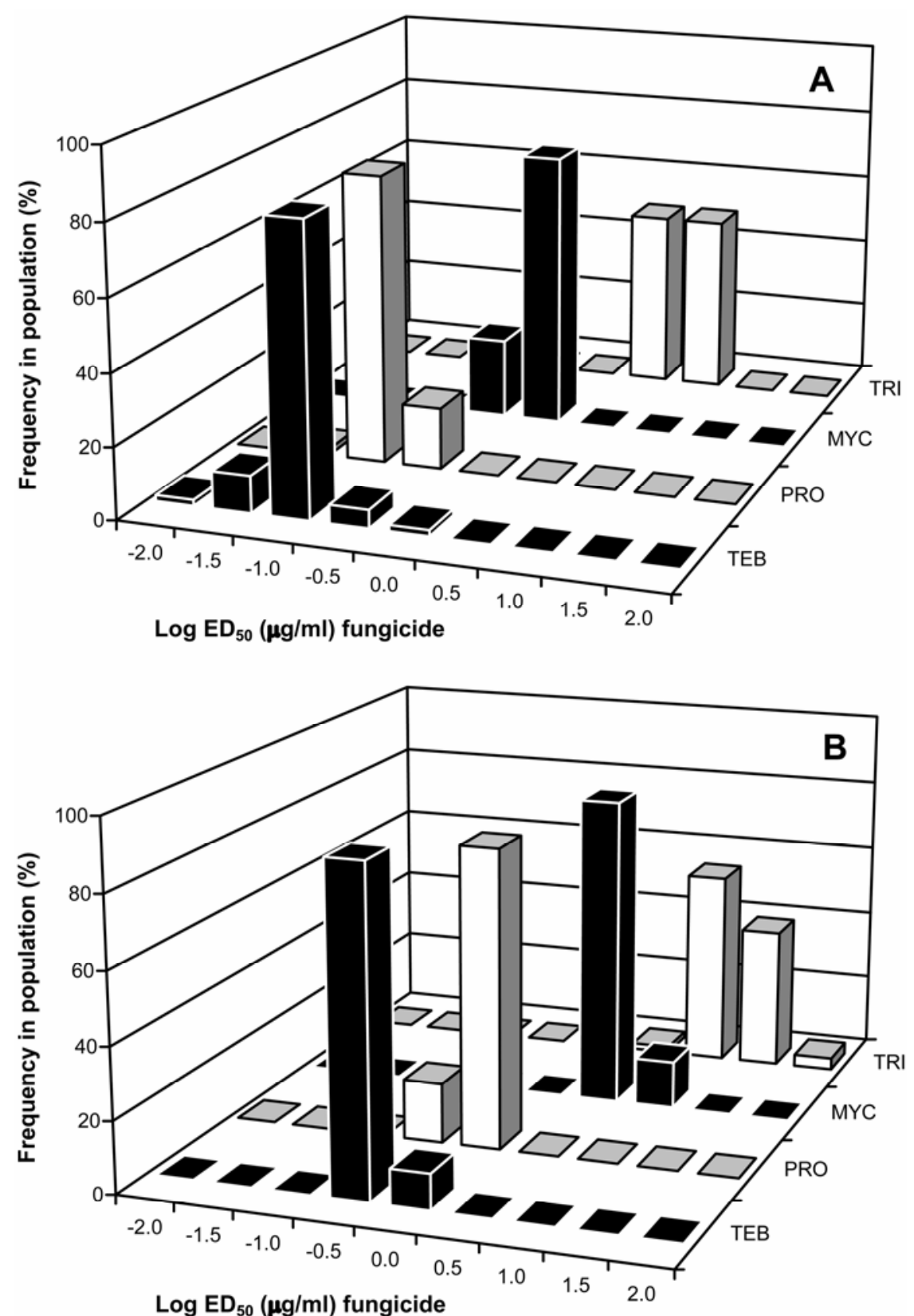

Fig. 5. Frequency distributions of sensitivities of Colletotrichum cereale isolates to myclobutanil (MYC), propiconazole (PRO), tebuconazole (TEB), and triadimefon (TRI) for $\mathbf{A}, 58$ isolates from baseline population TCGC and B, 60 isolates from demethylation inhibitor fungicide-exposed population AHCC. Log $50 \%$ effective dose $\left(\mathrm{ED}_{50}\right)$ values determined by bioassays using fungicide amended quarter-strength potato dextrose agar. $\mathrm{X}$-axis values represent the midpoint of each histogram class. erally were low. Analysis of both populations resulted in much higher coefficients of correlation, reflecting the possibility that highly resistant isolates likely share some general common mechanisms of resistance. Because the exact genetics and mechanisms of DMI-resistance is unclear, as discussed by Peever and Milgroom (29), the lack of perfect cross-sensitivity between isolates to the four fungicides was not unexpected.

The difference in intrinsic activities between the four DMI fungicides was apparent in both the baseline population TCGC and exposed population AHCC. This has a practical implication discussed by Erickson and Wilcox and Ypema et al. $(9,45)$ in their work with $U$. necator that showed that DMIs with higher intrinsic activities provide better disease control under field conditions. Our work suggests that tebuconazole $>$ propiconazole $>$ myclobutanil $>$ triadimefon for effectiveness against Colletotrichum cereale under field conditions. Although not directly tested in this work, these differences in activity are reflected by a field trial conducted in New Jersey in 2002 by Towers et al. (38). Here, seven applications of myclobutanil at 1.2 $\mathrm{kg} / \mathrm{ha}$, propiconazole at $0.50 \mathrm{~kg} / \mathrm{ha}$, tebuconazole at $1.5 \mathrm{~kg} / \mathrm{ha}$, or triadimefon at 1.5 $\mathrm{kg} / \mathrm{ha}$ were made at 14-day intervals from mid-May to mid-August for anthracnose control on a mixed annual bluegrass and creeping bentgrass putting green. At the end of the trial in September, tebuconazole provided $99 \%$ disease control, propiconazole provided $91 \%$ disease control, myclobutanil provided $61 \%$ disease control, and triadimefon provided $5.8 \%$ disease control (control relative to the check treatments, which had an average of $83 \%$ area showing symptoms).

Overall, the impact of shifts in DMI sensitivity for $C$. cereale is far from being fully understood. However, this work does lay the groundwork for monitoring shifts in $C$. cereale to DMIs and evaluating the effectiveness of resistance management programs for this pathogen in turfgrass systems. Future studies should address the molecular mechanisms of DMI resistance in $C$. cereale. For example, it is unknown if the mechanism of resistance in this pathogen is mediated by point mutation in or overexpression of the $14 \alpha$-demethylase

Table 6. Cross-sensitivity between demethylation inhibitor fungicides for two populations of Colletotrichum cereale

\begin{tabular}{lccc}
\hline & & \multicolumn{3}{c}{$\boldsymbol{R}^{\mathbf{2}}(\text { ANOVA } \boldsymbol{P})^{\mathbf{z}}$} & \\
\cline { 2 - 4 } Interaction & TCGC $($ baseline $)(\boldsymbol{n}=\mathbf{5 8})$ & AHCC $($ exposed $)(\boldsymbol{n}=\mathbf{6 0})$ & All $(\boldsymbol{n}=\mathbf{1 1 8})$ \\
\hline Triadimefon-myclobutanil & $0.24(<0.001)$ & $0.0113(0.42)$ & $0.58(<0.001)$ \\
Myclobutanil-propiconazole & $0.041(0.13)$ & $0.0021(0.71)$ & $0.75(<0.001)$ \\
Tebuconazole-propiconazole & $0.21(0.0034)$ & $0.0022(0.73)$ & $0.73(<0.001)$ \\
Triadimefon-propiconazole & $0.065(0.054)$ & $0.11(0.0092)$ & $0.54(<0.001)$ \\
Triadimefon-tebuconazole & $0.22(<0.001)$ & $0.017(0.32)$ & $0.48(<0.001)$ \\
Myclobutanil-tebuconazole & $0.34(<0.001)$ & $0.014(0.37)$ & $0.78(<0.001)$ \\
\hline
\end{tabular}

${ }^{\mathrm{z}}$ ANOVA $=$ analysis of variance. Coefficient of determination $\left(R^{2}\right)$ determined by comparison of $\log 50 \%$ effective dose values for each fungicide from individual isolates. 
gene as studied in $U$. necator and $V$. inaequalis, respectively $(6,34)$, or adenosine triphosphate binding cassette transporters such as those studied in $M$. graminicola (36).

The results from this study do indicate that DMI resistance is present in populations of C. cereale in California and it is not unreasonable to assume that resistance development has occurred in other locations where DMIs have been used for anthracnose control. Therefore, DMI resistance should be considered as a factor in anthracnose management programs. The large number of isolates examined in this study would allow for the detection of rare
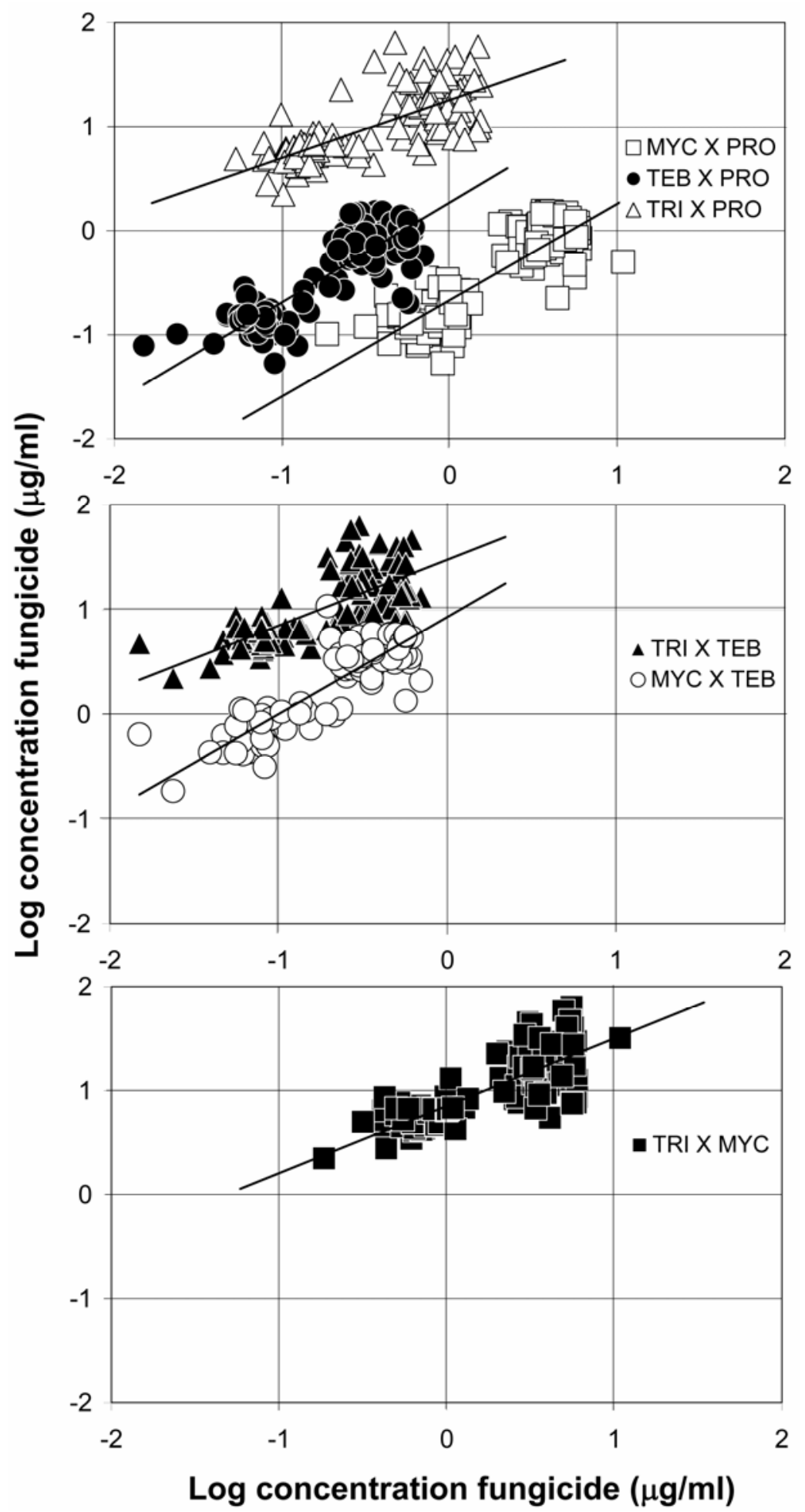

Fig. 6. Scatterplots of sensitivity data from two populations of Colletotrichum cereale (TCGC and AHCC) illustrating cross-sensitivity relationships between myclobutanil (MYC), propiconazole (PRO), tebuconazole (TEB), and triadimefon (TRI). Correlation was performed by comparing log $50 \%$ effective dose $\left(\mathrm{ED}_{50}\right)$ values for each fungicide from individual isolates. The listed interactions represent fungicides used for the $\mathrm{Y}$-axis $\times \mathrm{X}$-axis values respectively.

phenotypes that occurred in $1 \%$ or more of the population with $99 \%$ confidence (25), suggesting that the sensitivity data would well represent the current DMI-resistance situation for $C$. cereale populations regularly treated with DMI-fungicides. Because the full impact of these shifts is not understood, additional research must be performed to understand which fungicide use patterns and resistance management strategies are most effective. However, it is likely that applications of DMI fungicides for control of $C$. cereale at low-labeled or sub-label rates or at extended application intervals would result in both poor control and resistance development as suggested by Köller and Wilcox (23). Furthermore, DMI fungicides with higher intrinsic activity toward $C$. cereale, such as propiconazole and tebuconazole, should be used preferentially versus myclobutanil or triadimefon. Given the current problems with resistance development to other classes of fungicides $(42,43)$, and limits on multisite fungicide (chlorothalonil) use due to the 1996 U.S. federal Food Quality Protection Act, tactics to manage and delay resistance to DMIs for $C$. cereale must be implemented. Otherwise, it may be highly likely that systemic and curative fungicidal options for this disease will be severely limited.

\section{ACKNOWLEDGMENTS}

Part of this work was funded by Syngenta Professional Products with the assistance of D. Cox, K. Gard, D. Mosdell, and G. Olaya. We thank the many individual California golf course superintendents who participated in this study, including D. Reed, G. Olsen, and N. Checklenis; and W. Gelernter and L. Stowell (PACE Consulting) and lab members K. de la Cerda and J. Rios for their assistance.

\section{LITERATURE CITED}

1. Baldwin, N. A. 1993. Chemical control of Poa annua: a review. J. Sports Turf Res. Inst. 69:719.

2. Bartlett, D. W., Clough, J. M., Godwin, J. R., Hall, A. A., Hamer, M., and Parr- Dobrzanski, B. 2002. The strobilurin fungicides. Pest Manage. Sci. 58:649-662.

3. Burpee, L. L., Stephens, S. L., and MartinezEspinoza, A. D. 2004. Control of anthracnose caused by a benzimidazole- and QoI-resistant isolate of Colletotrichum graminicola, 2003. Fungic. Nematicide Tests 59:T016.

4. Burpee, L. L., Stephens, S. L., and MartinezEspinoza, A. D. 2005. Control of anthracnose caused by a benzimidazole- and QoI-resistant isolate of Colletotrichum graminicola, 2004. Fungic. Nematicide Tests 60:T054.

5. Crouch, J. A., Clarke, B. B., and Hillman, B. I. 2006. Unraveling evolutionary relationships among the divergent lineages of Colletotrichum causing anthracnose disease in turfgrass and corn. Phytopathology 96:46-60.

6. Delye, C., Laigret, F., and Corio-Costet, M.F. 1997. A mutation in the $14 \alpha$-demethylase gene of Uncinula necator that correlates with resistance to a sterol biosynthesis inhibitor. Appl. Environ. Microbiol. 63:2966-2970.

7. Detweiler, A. R., Vargas, J. M., and Berndt, W. L. 1989. Resistance of Colletotrichum graminicola to benomyl. Int. Turfgrass Soc. Res. J. 6:359-362.

8. Elliott, M. L. 1999. Effect of demethylation 
inhibiting fungicides on 'Tifgreen' bermudagrass quality. HortTechnology 9:195-197.

9. Erickson, E. O., and Wilcox, W. F. 1997. Distributions of sensitivities to three sterol demethylation inhibitor fungicides among populations of Uncinula necator sensitive and resistant to triadimefon. Phytopathology 87:784-791.

10. Fidanza, M. A., and Wilchak, T. 2005. Evaluation of fungicide tank-mixes for anthracnose control on annual bluegrass/creeping bentgrass, 2003. Fungic. Nematicide Tests 60:T025.

11. Fungicide Resistance Action Committee. 2006. FRAC List of Plant Pathogenic Organisms Resistant to Disease. Crop Life, Brussels, Belgium.

12. Golembiewski, R. C., Vargas, J. M.; Jones, A. L., and Detweiler, A. R. 1995. Detection of demethylation inhibitor (DMI) resistance in Sclerotinia homoeocarpa populations. Plant Dis. 79:491-493.

13. Green, D. E. 2004. Evaluation of foliar fungicides for crown and basal rot anthracnose control in annual bluegrass, 2003. Fungic. Nematicide Tests 59:T047

14. Heaney, S. P., Hall, A. A., Davies, S. A., and Olaya, G. 2000. Resistance to fungicides in the QoI-STAR cross resistance group: current perspectives. Pages 755-762 in: Brighton Crop Protection Conference-Pests and Diseases, vol. 3. Major Print Ltd., Nottingham, UK

15. Hsiang, T., Yang, L., and Barton, W. 1997. Baseline sensitivity and cross-resistance to demethylation-inhibiting fungicides in Ontario isolates of Sclerotinia homoeocarpa. Eur. J. Plant Pathol. 103:409-416.

16. Kane, R. T., and Smiley, R. W. 1983. Plant growth-regulating effects of systemic fungicides applied to Kentucky bluegrass. Agron. J. 75:469-473.

17. Karaoglanidis, G. S., and Thanassoulopoulos, C. C. 2003. Cross-resistance patterns among sterol biosynthesis inhibiting fungicides (SBIs) in Cercospora beticola. Eur. J. Plant Pathol. 109:929-934.

18. Köller, W. 1991. Fungicide resistance in plant pathogens. Pages 679-720 in: CRC Handbook of Pest Management in Agriculture, vol. 2, 2nd ed. D. Pimentel, ed. CRC Press, Boca Raton, FL.

19. Köller, W. 1992. Antifungal agents with target sites in sterol functions and biosynthesis. Pages 119-206 in: Target Sites of Fungicide Action. W. Köller, ed. CRC Press, Boca Raton, FL.

20. Köller, W. 1996. Recent developments in DMI resistance. Pages 301-311 in: Modern Antifungal Compounds. H. Lyr, P. E. Russel, and H. D. Sisler, eds. Intercept Ltd., Andover.

21. Köller, W. 1999. Chemical approaches to managing plant pathogens. Pages 337-376 in: Handbook of Pest Management. J. R. Ruberson, ed., Marcel Dekker, New York.

22. Köller, W., Parker, D. M., and Reynolds, K. L. 1991. Baseline sensitivities of Venturia inaequalis to sterol demethylation inhibitors. Plant Dis. 75:726-728.

23. Köller, W., and Wilcox, W. F. 1999. Evaluation of tactics for managing resistance of Venturia inaequalis to sterol demethylation inhibitors. Plant Dis. 83:857-863.

24. Köller, W., Wilcox, W. F., Barnard, J., Jones, A. L., and Braun, G. 1997. Detection and quantification of population shifts of Venturia inaequalis to sterol demethylation inhibitors. Phytopathology 87:184-190.

25. Leung, H., Nelson, R. J., and Leach, J. E. 1993. Population structure of plant pathogenic fungi and bacteria. Adv. Plant Pathol. 10:157205.

26. McCullough, M. D., and Wong, F. P. 2005. Evaluation of mid-season fungicide applications for the control of anthracnose on a mixed annual bluegrass and creeping bentgrass green in northern California, summer 2004. Fungic. Nematicide Tests 60:T056.

27. McManus, P. S., Best, V. M., Voland, R. P., and Leininger, B. L. 1999. Sensitivity of Monilinia oxycocci to fenbuconazole and propiconazole in vitro and control of cranberry cottonball in the field. Plant Dis. 83:445-450.

28. Miller, G. L., Stevenson, K. L., and Burpee, L. L. 2002. Sensitivity of Sclerotinia homoeocarpa isolates to propiconazole and impact on control of dollar spot. Plant Dis. 86:12401246.

29. Peever, T. L., and Milgroom, M. G. 1993. Genetic correlations in resistance to sterol biosynthesis-inhibiting fungicides in Pyrenophora teres. Phytopathology 83:1076-1082.

30. Reicher, Z. J., and Throssell, C. S. 1997. Effect of repeated fungicide applications on creeping bentgrass turf. Crop Sci. 37:910-915.

31. Reynolds, K. L., Brenneman, T. B., and Bertrand, P. F. 1997. Sensitivity of Cladosporium caryigenum to propiconazole and fenbuconazole. Plant Dis. 81:163-166.

32. Romero, R. A., and Sutton, T. B. 1997. Sensitivity of Mycosphaerella fijiensis, causal agent of black Sigatoka of banana, to propiconazole. Phytopathology 87:96-100.

33. Schnabel, G., Bryson, P. K., Bridges, W. C., and Brannen, P. M. 2004. Reduced sensitivity in Monilinia fructicola to propiconazole in Georgia and implications for disease management. Plant Dis. 88:1000-1004.

34. Schnabel, G., and Jones, A.L. 2001. The $14 \alpha$ demethylase (CYP51A1) gene is overex pressed in Venturia inaequalis strains resisance to myclobutanil. Phytopathology 91:102 110.

35. Smith, F. D., Parker, D. M., and Köller, W. 1991. Sensitivity distribution of Venturia inaequalis to the sterol demethylation inhibitor flusilazole, baseline sensitivity and implications for resistance monitoring. Phytopathology 81:392-396.

36. Stergiopoulos, I., and De Waard, M. A. 2002 Activity of azole fungicides and $\mathrm{ABC}$ transporters modulators on Mycosphaerella graminicola. J. Phytopathol. 150:313-320.

37. Szkolnik, M. 1981. Physical modes of action of sterol-inhibiting fungicides against apple diseases. Plant Dis. 65:981-985

38. Towers, G., Green, K., Weibel, E., Majumdar, P., and Clarke, B. B. 2003. Evaluation of fungicides for the control of anthracnose basal rot on annual bluegrass, 2002. Fungic. Nematicide Tests 58:T017.

39. Uddin, W., Soika, M. D., Shelton, J., and Soika, E. L. 2003. Control of anthracnose with fungicides on a putting green, 2002. Fungic. Nematicide Tests 58:T051.

40. Uddin, W., Soika, M. D., Shelton, J., and Soika, E. L. 2003. Effects of fungicides for control of anthracnose on a putting green, 2002. Fungic. Nematicide Tests 58:T050.

41. Uddin, W., Soika, M. D., Soika, E. L., and Francl, A. 2004. Management of Anthracnose basal rot on a putting green, 2003. Fungic Nematicide Tests 59:T031.

42. Wong, F. P. 2003. Baseline sensitivity distribution of Colletotrichum graminicola (turfgrass anthracnose) to thiophanate-methyl and detection of resistance in California populations. (Abstr.) Phytopathology 93:S91.

43. Wong, F. P., Midland, S. L., and de la Cerda, K. A. Occurrence and distribution of QoIresistant isolates of Colletotrichum cereale from annual bluegrass in California. Plant Dis. 91:1536-1546.

44. Wong, F. P., and Wilcox, W. F. 2002. Sensitivity to azoxystrobin among isolates of Uncinula necator: Baseline distribution and relationship to myclobutanil sensitivity. Plant Dis. 86:394404.

45. Ypema, H. L., Ypema, M., and Gubler, W. D. 1997. Sensitivity of Uncinula necator to benomyl, triadimefon, myclobutanil, and fenarimol in California. Plant Dis. 81:293-297. 